\title{
Global nitrogen and phosphorus fertilizer use for agriculture production in the past half century: shifted hot spots and nutrient imbalance
}

\author{
Chaoqun $\mathbf{L u}^{1,2}$ and Hanqin Tian ${ }^{2,3}$ \\ ${ }^{1}$ Department of Ecology, Evolution, and Organismal Biology, Iowa State University, Ames, IA 50011, USA \\ ${ }^{2}$ International Center for Climate and Global Change Research, and School of Forestry and Wildlife Sciences, \\ Auburn University, Auburn, AL 36849, USA \\ ${ }^{3}$ State Key Laboratory of Urban and Regional Ecology, Research Center for Eco-Environmental Sciences, \\ Chinese Academy of Sciences, Beijing 100085, China
}

Correspondence to: Chaoqun Lu (clu@iastate.edu)

Received: 22 July 2016 - Discussion started: 8 August 2016

Revised: 6 January 2017 - Accepted: 9 January 2017 - Published: 2 March 2017

\begin{abstract}
In addition to enhancing agricultural productivity, synthetic nitrogen $(\mathrm{N})$ and phosphorous $(\mathrm{P})$ fertilizer application in croplands dramatically alters global nutrient budget, water quality, greenhouse gas balance, and their feedback to the climate system. However, due to the lack of geospatial fertilizer input data, current Earth system and land surface modeling studies have to ignore or use oversimplified data (e.g., static, spatially uniform fertilizer use) to characterize agricultural $\mathrm{N}$ and $\mathrm{P}$ input over decadal or century-long periods. In this study, we therefore develop global time series gridded data of annual synthetic $\mathrm{N}$ and $\mathrm{P}$ fertilizer use rate in agricultural lands, matched with HYDE 3.2 historical land use maps, at a resolution of $0.5^{\circ} \times 0.5^{\circ}$ latitude-longitude during 1961-2013. Our data indicate $\mathrm{N}$ and $\mathrm{P}$ fertilizer use rates on per unit cropland area increased by approximately 8 times and 3 times, respectively, since the year 1961 when IFA (International Fertilizer Industry Association) and FAO (Food and Agricultural Organization) surveys of country-level fertilizer input became available. Considering cropland expansion, the increase in total fertilizer consumption is even larger. Hotspots of agricultural $\mathrm{N}$ fertilizer application shifted from the US and western Europe in the 1960s to eastern Asia in the early 21st century. $\mathrm{P}$ fertilizer input shows a similar pattern with an additional current hotspot in Brazil. We found a global increase in fertilizer $\mathrm{N} / \mathrm{P}$ ratio by $0.8 \mathrm{~g} \mathrm{~N} \mathrm{~g}^{-1} \mathrm{P}$ per decade $(p<0.05)$ during 1961-2013, which may have an important global implication for human impacts on agroecosystem functions in the long run. Our data can serve as one of critical input drivers for regional and global models to assess the impacts of nutrient enrichment on climate system, water resources, food security, etc. Datasets available at doi:10.1594/PANGAEA.863323.
\end{abstract}

\section{Introduction}

Agricultural fertilizer use is one of the important land management practices that has alleviated nitrogen limitation in cropland and substantially increased crop yield and soil fertility over the past century (Vitousek et al., 1997; Tilman et al., 2002). Since the generation of the Haber-Bosch process in the early 20th century, chemical nitrogen (N) fertilizer production has converted a large amount of unreactive $\mathrm{N}$ to reactive forms (Galloway et al., 2004). Chemical phos- phorus $(\mathrm{P})$ fertilizer production was promoted along with the phosphorus acid. On the one hand, as a critical component of the "green revolution", the dramatic increase in fertilizer production and application has contributed considerably in raising agricultural productivity and reducing hunger worldwide (Smil, 2002; Erisman et al., 2008). On the other hand, excessive fertilizer use is proven to cause a number of environmental and ecological problems within and outside of farmlands, such as air pollution, soil acidification and degradation, water eutrophication, crop yield reduction, and un- 
dermining of the sustainability of food and energy production from agricultural fields (Bouwman et al., 2005; Ju et al., 2009; Vitousek et al., 2009; Guo et al., 2010; Sutton et al., 2011; Tian et al., 2012; Lu and Tian, 2013).

Large spatial and temporal variations exist in chemical fertilizer use across the world. China, the US, and India together accounted for over $50 \%$ of fertilizer consumption globally and they demonstrated a contrasting changing trend over the past century due to the status of economic and agricultural development (FAOSTAT, 2015). The rates and spatiotemporal patterns of $\mathrm{N}$ and $\mathrm{P}$ fertilizer use are key input drivers for inventory- and process-based land modeling studies to reliably estimate agroecosystem production and the greenhouse gas budget (Mosier et al., 1998; Zaehle et al., 2011; Stocker et al., 2013; Tian et al., 2015). Nutrient input-related processes affect a wide variety of plant physiological, biogeochemical, and hydrological variables (e.g., crop productivity, yield, evapotranspiration, $\mathrm{N}_{2} \mathrm{O}$ emission, $\mathrm{N}$ and $\mathrm{P}$ leaching from agricultural runoff, and land-to-water nutrient export) and their responses to other environmental drivers (e.g., $\mathrm{CO}_{2}$ fertilization effect). However, there is still a lack of data for describing long-term spatially explicit agricultural input of $\mathrm{N}$ and $\mathrm{P}$ through chemical fertilizer use across the globe.

The International Fertilizer Industry Association (IFA) and the Food and Agricultural Organization (FAO) provided data for annual fertilizer consumption amount since 1961, which is the most complete country-level record of fertilizer use over a long period of time, and the data have been used in multiple bottom-up nutrient budget analyses (e.g., Mosier et al., 1998; Galloway et al., 2004; Bouwman et al., 2005, 2013a). By assuming uniform fertilizer application rate nationwide, many process-based modeling studies considering management practices (Zaehle et al., 2011; Stocker et al., 2013) have used this data set as an important driver for agroecosystems; however, the spatial variations in fertilizer use within countries have been overlooked. Tian et al. (2015) updated FAO-based fertilizer use data by using detailed regional information in China, India, and the US to replace country-uniform data and keeping the other countries the same as FAO statistics. They partially demonstrated withincountry variations through province-level census in China and state-level census in India and US (Tian et al., 2010; Lu and Tian, 2013; Banger et al., 2015). Based on countrylevel crop-specific fertilizer record ("Fertilizer Use by Crop 2002", from IFADATA) and a global distribution map of 175 crops (Monfreda et al., 2008), Potter et al. (2010) generated annual $\mathrm{N}$ and $\mathrm{P}$ fertilizer application data across the globe at a spatial resolution of $0.5^{\circ}$ latitude by longitude. These data contain most crop-specific variations in $\mathrm{N}$ and $\mathrm{P}$ fertilizer use over space, but they only represent average fertilizer application pattern in the period from 1994 to 2001 and cannot meet the timescale of long-term land surface modeling. Likewise, Mueller et al. (2012) used a similar approach to distribute crop- and crop-group-specific fertilizer use rates and combine multisource national and subnational nutrient consumption data to harmonize fertilizer use rate. However, their data only represent the status around 2000. Therefore, in this study, we develop a spatially explicit time series agricultural $\mathrm{N}$ and $\mathrm{P}$ fertilizer use data set by combining country-level fertilizer use records, crop-specific fertilizer use data, global maps of annual cropland area, and spatial distributions of crop types at a $0.5^{\circ}$ resolution during the period 1961-2013. This newly developed data set displayed within-country heterogeneity of agricultural fertilizer use while keeping the country-level total fertilizer consumption amount consistent with IFA data. It has been recently incorporated as one of the key environmental drivers for global model simulation studies and model-model intercomparison projects (e.g., $\mathrm{N}_{2} \mathrm{O}-\mathrm{MIP}$; Tian et al., personal communication, 2016). To facilitate Earth system modeling and inventory-based studies, these global $\mathrm{N}$ and $\mathrm{P}$ fertilizer use data will be updated annually based on the most recent IFA-FAO country-level statistics data and historical land use maps.

\section{Methods}

The basic principle is to spatialize the country-level $\mathrm{N}$ and $\mathrm{P}$ fertilizer use amount to gridded maps of fertilizer use rate on per unit area of cropland in the period 1961-2013 (Fig. 1), during which IFA and FAO have annual records for most countries. Here we adopt "grand total $\mathrm{N}$ and $\mathrm{P}_{2} \mathrm{O}_{5}$ " from IFA statistical data in thousands of tons of nutrients per country. The grand total amount includes nutrients from straight and compound forms. We convert grams of $\mathrm{P}_{2} \mathrm{O}_{5}$ in the IFA database and Heffer (2013) to grams of P by multiplying by the ratio of $62 / 142$.

Regarding crop-specific $\mathrm{N}$ and $\mathrm{P}$ fertilizer use rates, the database of crop-specific fertilizer use from the IFA (Heffer, 2013) provides the total amount of $\mathrm{N}$ and $\mathrm{P}$ fertilizer use in 13 crop groups at country level, which includes 27 selected countries (considering EU-27 as single countries, Fig. 2) in 2010-2011. It accounts for over $94 \%$ of global fertilizer consumption. M3-crop data, which include detailed distribution maps of crop types developed by Monfreda et al. (2008), depict the harvested area for 175 crops in the year 2000 at 5 arcmin resolution for latitude by longitude. This unit is a proportion of the grid cell area and the values could be larger than 1 because of multiple cropping. We calculated the harvested area of these 13 crop groups (i.e., wheat, rice, maize, other cereal, soybean, oil palm, other soil seed, fiber, sugar, roots, fruit, vegetable, and others) in the corresponding 26 countries and EU-27. We obtained country-level cropspecific $\mathrm{N}$ and $\mathrm{P}$ fertilizer use rates by dividing crop-specific fertilizer consumption amount by harvested area of each crop group. Here, by using harvested area, instead of area of arable land, we consider the effect of multiple cropping on the calculation of $\mathrm{N}$ and $\mathrm{P}$ fertilizer use rate to avoid overestimating nutrient input in cropland. These tabular data were interpo- 


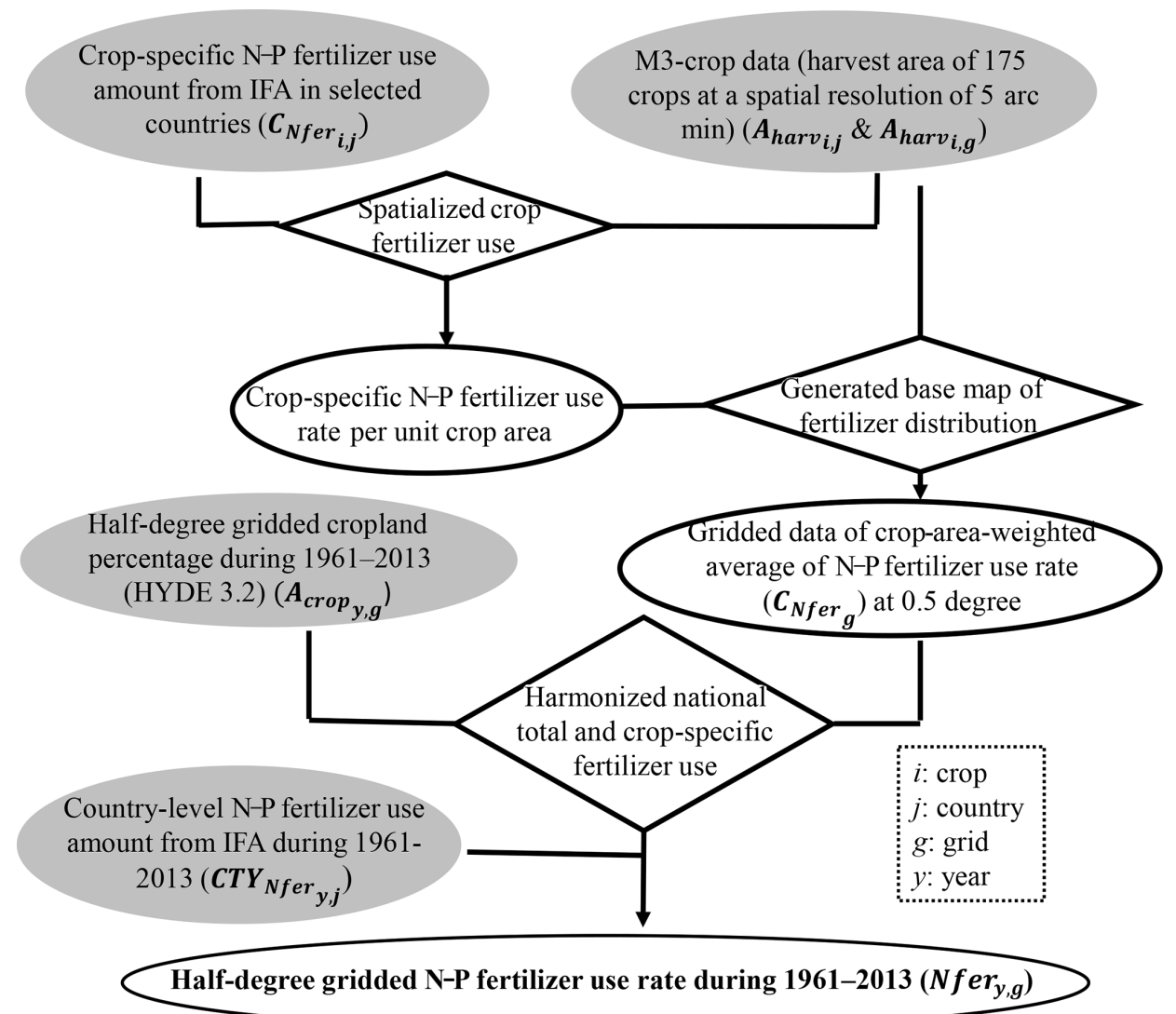

Figure 1. Diagram of the workflow for developing the database of global annual $\mathrm{N}$ and $\mathrm{P}$ fertilizer use rate during the period 1961-2013. Oval boxes indicate data elements, among which the gray ones show the raw data involved in fertilizer data development and the white ones are the middle and final data products. Diamond boxes indicate process elements.

lated to generate spatial maps of $\mathrm{N}$ and $\mathrm{P}$ fertilizer use rate for each crop group. Combined with harvested area of each crop, we produced the area-weighted average of $\mathrm{N}$ and $\mathrm{P}$ fertilizer use rate in each grid cell, which serves as a baseline map to downscale country-level fertilizer use.

$\overline{C_{\mathrm{Nfer}_{g}}}=\frac{\sum_{i}\left(\frac{C_{\mathrm{Nerr}_{i, j}}}{A_{\operatorname{harv}_{i, j}}} \times A_{\mathrm{harv}_{i, g}}\right)}{\sum_{i} A_{\mathrm{harv}_{i, g}}}$,

where $\overline{C_{\mathrm{Nfer}}}$ is the area-weighted average of crop-specific nutrient $(\mathrm{N}$ and $\mathrm{P})$ fertilizer use rate (i.e., gridded baseline fertilizer use rate, in the unit of $\mathrm{gN}_{\mathrm{N}}$ or $\mathrm{P} \mathrm{m}^{-2} \mathrm{yr}^{-1}$ ) at a resolution of $0.5^{\circ} \times 0.5^{\circ} . C_{\mathrm{Nfer}}$ and $A_{\text {harv }}$ are crop-specific N and $\mathrm{P}$ fertilizer use amount ( $\mathrm{g} \mathrm{N}$ or $\mathrm{gP})$ and harvested area $\left(\mathrm{m}^{2}\right)$, respectively, for crop type $i$, country $j$, and grid cell $g$ (Fig. 1). Here, the harvested areas of M3-crops were aggregated to a half degree to meet the expected resolution of our final product.

\subsection{IFA-based national fertilizer use interpolation}

The countries included in IFA country-level time series surveys but excluded by crop-specific fertilizer use databases (yellow color in Fig. 2) were depicted with IFA-reported country average fertilizer use rate. To calculate them, we divided country- and continent-scale annual fertilizer consumption amount from the IFA by corresponding cropland area calculated from HYDE 3.2 (Klein Gildewijk, 2016) to get half-degree gridded $\mathrm{N}$ and $\mathrm{P}$ fertilizer use rates during 1961-2013. In this step, we assume that the $\mathrm{N}$ and $\mathrm{P}$ fertilizer is evenly applied to croplands of each country. In addition, to represent the status of countries not included in the IFA (green in Fig. 2), the amount of fertilizer application in IFAincluded countries was subtracted from continental total, and the remaining fertilizer was assumed to be evenly applied in the rest of the croplands on each continent. These non-IFA countries together cover $\sim 8 \%$ of global croplands and account for less than $1 \%$ of global synthetic $\mathrm{N}$ and $\mathrm{P}$ fertilizer consumption. Several countries (e.g., former Soviet Union, former Czechoslovakia, former Yugoslavia) were broken up in the 1990s, and the emergent countries only have fertilizer use archived thereafter. We use average fertilizer use rate 


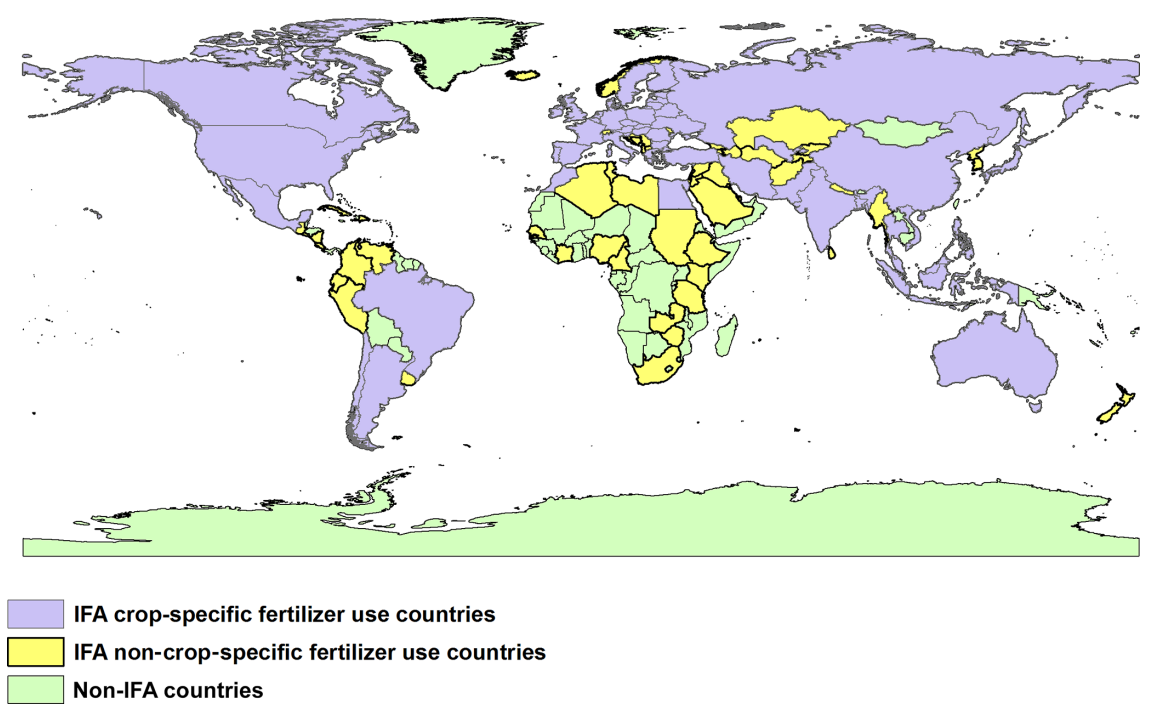

Figure 2. Countries with and without crop-specific fertilizer use records from the IFA database in 2010-2011 (Heffer et al., 2013) and those excluded by IFA data records.

at per unit cropland area in the former countries to represent new countries' agricultural nutrient input before their existence. Country boundary maps are derived from "World Country Admin Boundary Administrative Areas Shapefile with FIPS codes" by Global Administrative Areas (2012), in which country administrative boundaries, country names, and two-digit FIPS codes are provided across the world.

\subsection{Harmonizing national total and crop-specific fertilizer use rate}

In order to keep the national total $\mathrm{N}$ and $\mathrm{P}$ fertilizer amounts consistent with the IFA inventory, we calculated countrylevel ratios between the time series (1961-2013) national fertilizer use amount from the IFA and the product of gridded baseline fertilizer use rate $\left(\overline{C_{\mathrm{Nfer}_{g}}}\right)$ and gridded cropland area delineated by HYDE 3.2. These tabular country-level regulation ratio data were interpolated into half-degree maps, which were multiplied by gridded baseline fertilizer use rate $\left(\overline{C_{\mathrm{Nfer}}}\right)$ to generate maps of "real" $\mathrm{N}$ and $\mathrm{P}$ fertilizer use rate during 1961-2013. This approach was only used in the grid cells containing croplands according to HYDE 3.2. In the other areas, fertilizer use rate is zero.

$R_{\mathrm{Nfer}_{y, j}}=\frac{\mathrm{CTY}_{\mathrm{Nfer}_{y, j}}}{\sum_{g=1}^{g=n \text { in country } j}\left(\overline{C_{\mathrm{Nfer}_{g}}} \times A_{\text {crop }_{y, g}}\right)}$,

where $R_{\mathrm{Nfer}_{y, j}}$ is the regulation ratio (unitless) in the year $y$ and country $j$. CTY $\mathrm{Nfer}_{y, j}$ is national total $\mathrm{N}$ fertilizer use amount (unit is $\mathrm{g} \mathrm{Nyr}^{-1}$ or $\mathrm{g} \mathrm{Pyr}^{-1}$ ) derived from the IFA database in a specific year, and $A_{\text {crop }_{y, g}}$ is the area of cropland (unit is $\mathrm{m}^{2}$ ) retrieved from the historical land use data (HYDE 3.2) in the year $y$ and grid $g$. Here we have aggre- gated annual cropland area of HYDE 3.2 into half degrees.

$\mathrm{Nfer}_{y, g}=\overline{C_{\mathrm{Nfer}_{g}}} \times R_{\mathrm{Nfer}_{y, g}}$,

where real gridded $\mathrm{N}$ and $\mathrm{P}$ fertilizer use rates $\left(\mathrm{Nfer}_{y, g}\right.$, unit is $\mathrm{g} \mathrm{N}$ or $\mathrm{P} \mathrm{m}^{-2}$ cropland $\mathrm{yr}^{-1}$ ) in the year $y$ and grid $g$ are the product of gridded baseline $\mathrm{N}$ fertilizer use rate and the modification ratio $\left(R_{\mathrm{Nfer}_{y, j}}\right)$ in the corresponding year and grid cell.

It is notable that EU-27 has the same crop-specific fertilizer use rate for each crop group, but the IFA-based countrylevel fertilizer use amount is different among countries and years; thus, annual maps of regulation ratios are different spatially. Therefore, the final product shows spatially variant $\mathrm{N}$ and $\mathrm{P}$ fertilizer use rates in the region of EU-27.

\section{Results}

Our data indicate that $\mathrm{N}$ fertilizer consumption increased

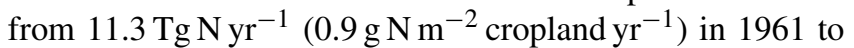
107.6 $\mathrm{Tg} \mathrm{N} \mathrm{yr}^{-1}\left(7.4 \mathrm{~g} \mathrm{~N} \mathrm{~m}^{-2}\right.$ cropland $\mathrm{yr}^{-1}$ on average) in 2013 and that $P$ fertilizer consumption increased from 4.6 to $17.5 \mathrm{Tg} \mathrm{Pyr}^{-1}$ (0.4 to $1.2 \mathrm{~g} \mathrm{P} \mathrm{m}^{-2}$ cropland $\mathrm{yr}^{-1}$ on average) during the same period (Fig. 3). Increase in global total fertilizer use amount is derived from both cropland expansion and raised fertilizer application rate in per unit cropland area. In 2013, the top five fertilizer-consuming countries (China, India, the US, Brazil, and Pakistan for $\mathrm{N}$ fertilizer and China, India, the US, Brazil, and Canada for $\mathrm{P}$ fertilizer) together accounted for $63 \%$ of global fertilizer consumption. China alone shared $31 \%$ of global $\mathrm{N}$ fertilizer consumption with an annual increasing rate of $0.7 \mathrm{Tg} \mathrm{N} \mathrm{y}^{-1}$ or $0.6 \mathrm{~g} \mathrm{~N} \mathrm{~m}^{-2}$ cropland $\mathrm{yr}^{-1}\left(R^{2}=0.98\right)$ during 1961-2013 (Fig. 4), while India showed a much smaller increasing 

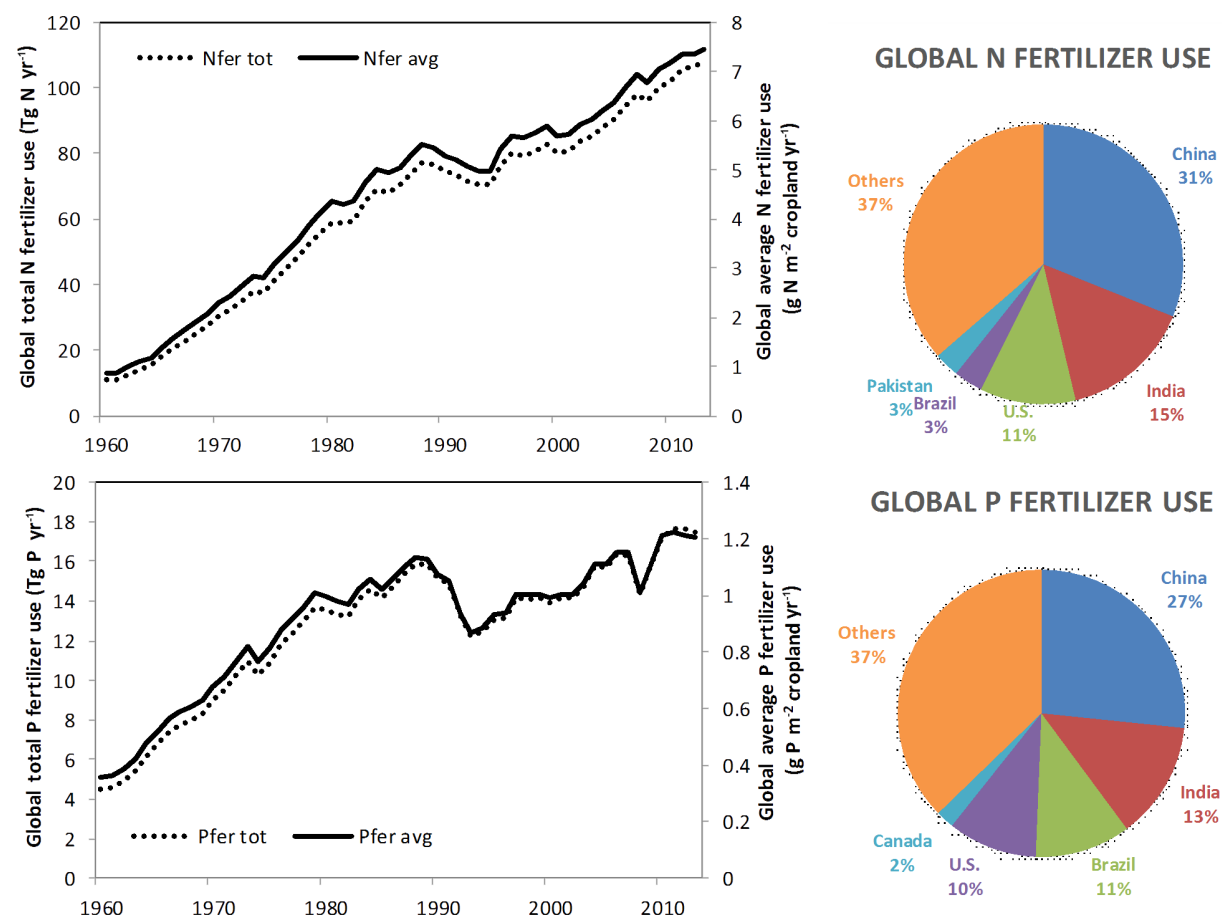

GLOBAL P FERTILIZER USE

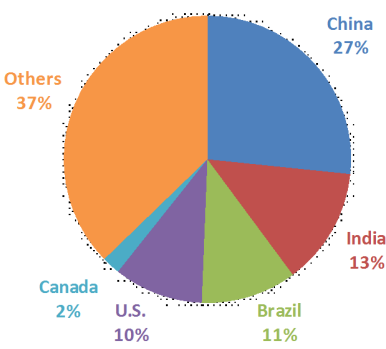

Figure 3. Temporal patterns of global nitrogen $(\mathrm{N})$ and phosphorous $(\mathrm{P})$ fertilizer use in terms of total amount (tot) and average rate on per unit of cropland area (avg) per year. Pie charts show the proportion of $\mathrm{N}$ and $\mathrm{P}$ fertilizer use in the top five fertilizer-consuming countries and others in the year 2013 .

trend of $0.3 \mathrm{Tg} \mathrm{N} \mathrm{yr}^{-1}$ or $0.2 \mathrm{~g} \mathrm{~N} \mathrm{~m}^{-2}$ cropland $\mathrm{yr}^{-1}$ per year $\left(R^{2}=0.97\right)$. N fertilizer use rate in the US increased by $0.4 \mathrm{Tg} \mathrm{Nyr}^{-1}$ or $0.2 \mathrm{~g} \mathrm{~N} \mathrm{~m}^{-2}$ cropland $\mathrm{yr}^{-1}$ per year during 1961-1980 and leveled off thereafter. P fertilizer use in these three countries demonstrated a similar pattern: a more rapid increase in China $\left(0.1 \mathrm{Tg} \mathrm{Pyr}^{-1}\right)$ than in India $\left(0.06 \mathrm{Tg} \mathrm{Pyr}^{-1}\right)$ and the US $\left(0.05 \mathrm{Tg} \mathrm{Pyr}^{-1}\right.$ during $1961-$ 1980 and leveled off thereafter). Brazil accounted for 3 and $11 \%$ of global $\mathrm{N}$ and $\mathrm{P}$ fertilizer consumption, respectively. $\mathrm{N}$ fertilizer use rate in Brazil has gradually increased since the early 1990s and has now reached half of the agricultural $\mathrm{N}$ input level in the US, while its $\mathrm{P}$ fertilizer use rate ranked the global top in 1980, declined thereafter, and regrew from 2000, demonstrating the second highest per unit cropland P fertilizer use rate next to China. Pakistan shared $3 \%$ of global total $\mathrm{N}$ fertilizer use, but its average cropland application rate increased dramatically, with an annual increase rate of $0.3 \mathrm{~g} \mathrm{~N} \mathrm{~m}^{-2}$ cropland $\mathrm{yr}^{-1}\left(R^{2}=0.97\right)$, second only to China (Fig. 4).

Agricultural $\mathrm{N}$ fertilizer use rate peaked in the US and western Europe in the 1960s, and the hot spots gradually moved to western Europe and eastern Asia in the 1980s and 1990s. They then moved to eastern Asia in the early 21 st century (Fig. 5). Large areas of cropland in eastern and southeastern China stand out due to extremely high $\mathrm{N}$ fertilizer input (e.g., more than $30 \mathrm{~g} \mathrm{~N} \mathrm{~m}^{-2} \mathrm{yr}^{-1}$ ). Northern India and western Europe received $10-20 \mathrm{~g} \mathrm{~N} \mathrm{~m}^{-2} \mathrm{yr}^{-1}$ up to now.
South America also experienced a rapid increase in $\mathrm{N}$ fertilizer use rate during the past 54 years, particularly for small areas of Brazil, with $\mathrm{N}$ input reaching similar levels as the US. Although cropland expansion widely occurred in Africa, its average $\mathrm{N}$ fertilizer use rate was enhanced slowly, with most areas still receiving less than $1.5 \mathrm{~g} \mathrm{~N} \mathrm{~m}^{-2} \mathrm{yr}^{-1}$ in 2013 . Australia demonstrated a similar low level of agricultural $\mathrm{N}$ input (less than $5 \mathrm{~g} \mathrm{~N} \mathrm{~m}^{-2} \mathrm{yr}^{-1}$ in 2013). $\mathrm{N}$ fertilizer use in Russia peaked in the 1980s and then declined in the following decades. It is argued that after 1990 the major reason for fertilizer use drop was a severe economic depression due to the breakup of the Soviet Union and the following conversion to market economies (Ivanova and Nosov, 2011).

The hot spot of agricultural $\mathrm{P}$ fertilizer input centered in Europe before the 1980s and then shifted to central China and a small area of Brazil, with an input rate of more than $3 \mathrm{~g} \mathrm{P} \mathrm{m}^{-2}$ cropland $\mathrm{yr}^{-1}$ in 2013 (Fig. 6). $\mathrm{P}$ input in China showed a significant increasing trend during 19612013 ( $p<0.05$ ), while in Brazil it peaked in the early 1980s and declined thereafter, growing again since 2000. Most agricultural areas across the rest of world were characterized by $\mathrm{P}$ input of less than $1 \mathrm{~g} \mathrm{P} \mathrm{m}^{-2}$ cropland $\mathrm{yr}^{-1}$, except India, western Europe, and a small area of the US, receiving 1$1.5 \mathrm{~g} \mathrm{P} \mathrm{m}^{-2}$ cropland $\mathrm{yr}^{-1}$ in 2013. $\mathrm{P}$ fertilizer use rate has remained relatively stable in the US since 1980 . Similar to agricultural $\mathrm{N}$ fertilizer use, the increase in total $\mathrm{P}$ fertilizer amount in Africa was primarily driven by cropland expan- 

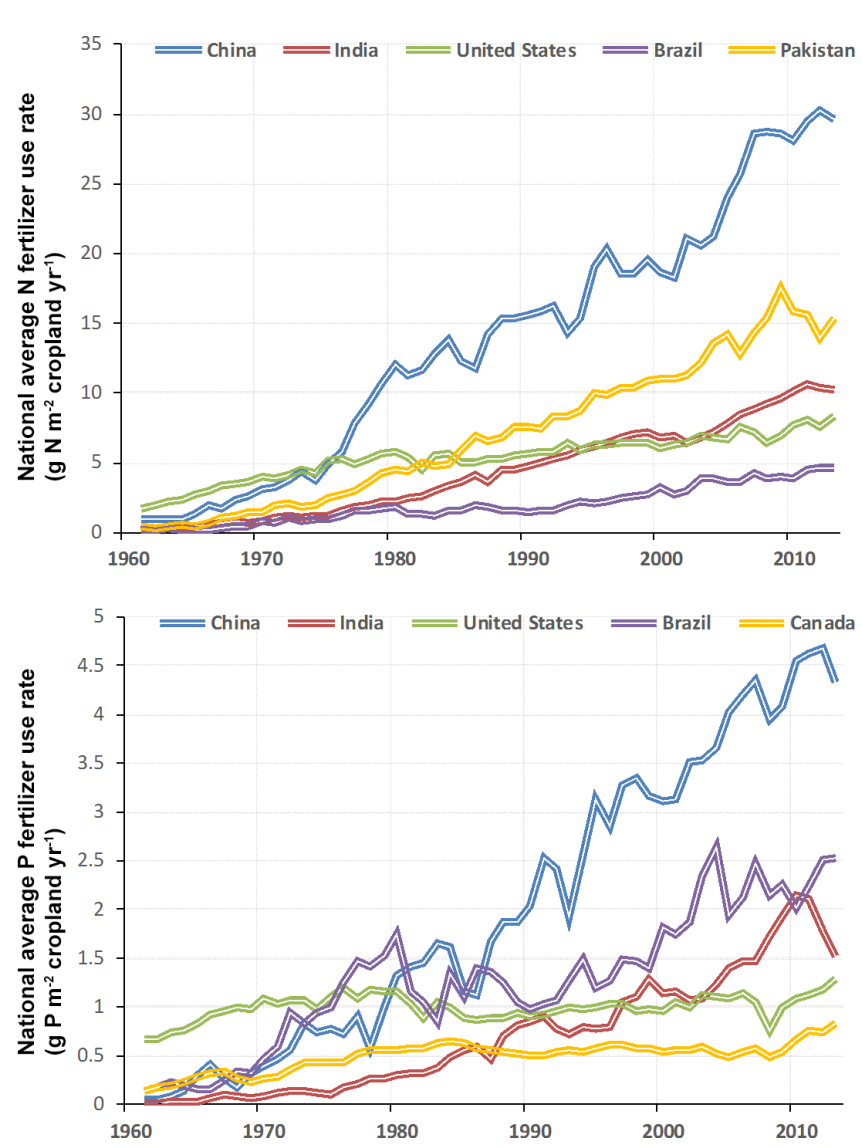

Figure 4. Interannual variations in national average $\mathrm{N}$ and $\mathrm{P}$ fertil-

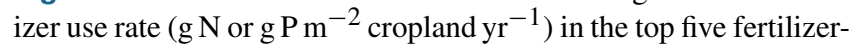
consuming countries during 1961-2013.

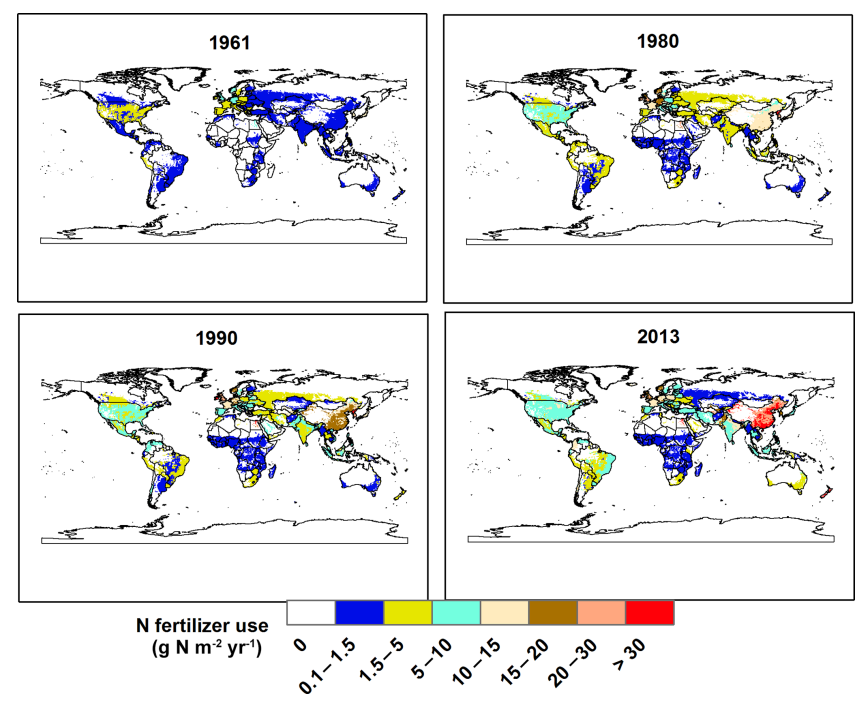

Figure 5. Spatial distribution of global agricultural nitrogen $(\mathrm{N})$ fertilizer use in the year 1961, 1980, 1990, and 2013. Colors show $\mathrm{N}$ fertilizer use rate in per square meter cropland of each pixel.

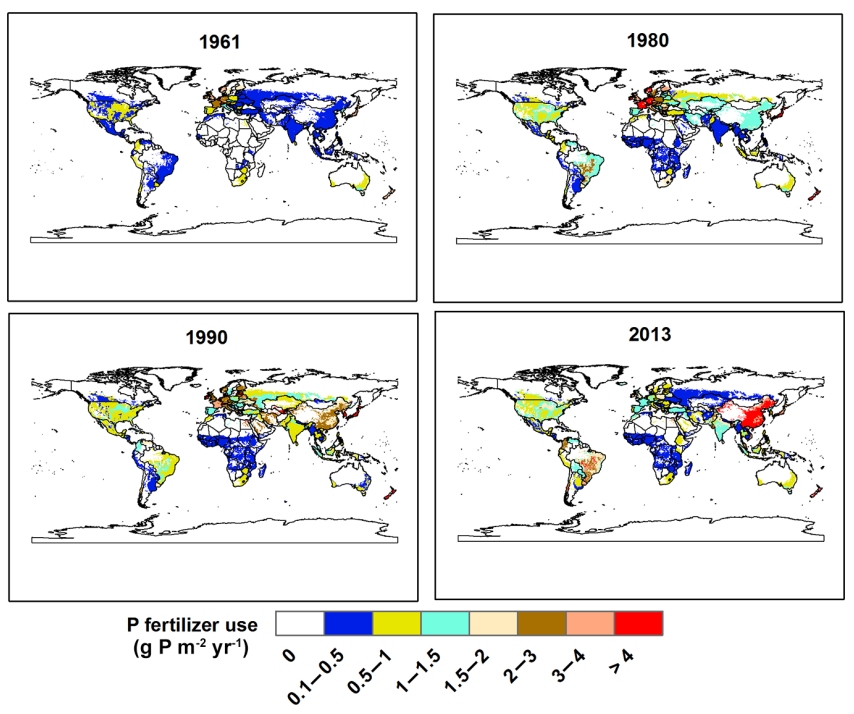

Figure 6. Spatial distribution of global agricultural phosphorus (P) fertilizer use in the years 1961, 1980, 1990, and 2013. Colors show $\mathrm{P}$ fertilizer use rate in per square meter of cropland in each pixel.

sion, and its input rate per unit of cropland area was constantly low, less than $0.5 \mathrm{~g} \mathrm{P} \mathrm{m}^{-2} \mathrm{yr}^{-1}$ during the past half century. Likewise, $\mathrm{P}$ fertilizer use rate in Russia increased in the 1980s and began to decline after 1990 .

We found that the enhancement of $\mathrm{N}$ fertilizer use is faster than that of $\mathrm{P}$ fertilizer use, leading to an increase in the $\mathrm{N} / \mathrm{P}$ ratio in synthetic fertilizer consumption from 2.4 to $6.2 \mathrm{~g} \mathrm{~N} \mathrm{~g}^{-1} \mathrm{P}$ (an increase of $0.8 \mathrm{~g} \mathrm{~N} \mathrm{~g}^{-1} \mathrm{P}$ per decade, $p<$ 0.05) during 1961-2013. This increase mainly took place in Europe, northern Asia, and small areas of South America and Africa (Fig. 7). However, fertilizer N / P ratio declined in China and India from over $9 \mathrm{~g} \mathrm{~N} \mathrm{~g}^{-1} \mathrm{P}$ in 1961 to 5$9 \mathrm{~g} \mathrm{~N} \mathrm{~g}^{-1} \mathrm{P}$ at present, which is mainly caused by extremely low P fertilizer input in these two countries before 1980. It has remained relatively stable in the US and most countries in Africa since 1980. Up to now, fertilizer N / P ratio in the Northern Hemisphere has generally been higher (more than $5 \mathrm{~g} \mathrm{~N} \mathrm{~g}^{-1} \mathrm{P}$ ) than that in the Southern Hemisphere.

\section{Discussion}

\subsection{Comparison with other studies}

In this study, we use M3-crop to spatialize crop-specific fertilizer use rate and then use HYDE 3.2 to disaggregate the annual national IFA fertilizer use record to grid cells with cropland. Therefore, the changes in fertilizer use rate shown in our data could reflect the comprehensive human disturbances in cropland area and distribution as well as national total fertilizer inputs at annual time steps (Figs. 5 and 6). In addition, in spatializing fertilizer data, the approach we used here based on crop-specific fertilizer use rate is more reliable than national, provincial, state, or county-based fertilizer de- 
velopment, which assumes uniform fertilizer input rate in a certain region (Zaehle et al., 2011; Lu and Tian, 2013; Tian et al., 2015). A regionally uniform rate overlooks fertilizer use differences among crops. The 13 crop groups we adopted to spatialize national fertilizer input include the top fertilizerconsuming crops (i.e., wheat, maize, soybean, rice, oil palm) and aggregate the rest of crops into other cereal, other soil seed, fiber, sugar, roots, fruit, vegetable, and others, which keeps cross-country cross-crop heterogeneity of fertilizer use in data development. Overall, combined with historical land use data (e.g., HYDE 3.2), our half-century-long global fertilizer maps at a $0.5^{\circ} \times 0.5^{\circ}$ resolution can be used to force Earth system models for assessing agroecosystem productivity, greenhouse gas fluxes, $\mathrm{N}$ and $\mathrm{P}$ export through agricultural runoff, and their feedbacks to the climate system.

This newly developed database is based on IFA countrylevel time series statistics, and its spatial distribution follows the pattern of crop-specific fertilizer use rate and gridded harvest area of major crop types. Our data are comparable to other existing estimates in terms of global $\mathrm{N}$ and $\mathrm{P}$ fertilizer consumption amount (Table 1). Our global total is very close to IFA statistical data. Only a few existing data (e.g., Potter et al., 2010; Mueller et al., 2012) characterize the spatial heterogeneity and hot spots of $\mathrm{N}$ and $\mathrm{P}$ fertilizer use in agricultural land, but none of them spans long enough to facilitate a modeling study to capture the legacy effects of historical fertilizer input. Potter et al. (2010) used a similar approach as we did and developed geospatial data of $\mathrm{N}$ and $\mathrm{P}$ inputs from fertilizer and manure across the globe. However, they did not consider annual land cover change and the resulting changes in spatial patterns of agricultural fertilizer use by using a one-phase M3-crop map, which represents an average cropland distribution in the period 1997-2003 (Monfreda et al., 2008). Likewise, Mueller et al. (2012) revised Potter's approach by incorporating national and subnational fertilizer application data for crops and crop groups, harmonizing with FAO consumption record and allocating fertilizer to crop and pasture areas derived from the M3-crop map. Potter et al. (2010) and Mueller et al. (2012) both demonstrate total $\mathrm{N}$ or $\mathrm{P}$ fertilizer use on a per unit grid cell area. In order to compare them with our data in the year 2000, we converted these two data products to grams of $\mathrm{N}$ or $\mathrm{P}$ per square meter of cropland area by dividing grid-level total fertilizer amount by crop areas from M3-crop data (Fig. 8). We found that the hot spots of global $\mathrm{N}$ and $\mathrm{P}$ fertilizer use rate are roughly consistent among these three data sets. The major differences are likely caused by the following reasons: (1) cropland area and distribution derived from HYDE 3.2 (used in our study) and M3-crop (used to delineate fertilizer use area in Potter et al., 2010 and Mueller et al., 2012) do not match in some areas such as western China, the western US, central Asian countries, northern Africa, and Australia; (2) the crop-specific fertilizer use data in 2010-2011 (Fig. 2) used in our study covered more countries in northern Asia, but less in Africa and South America compared to IFA data
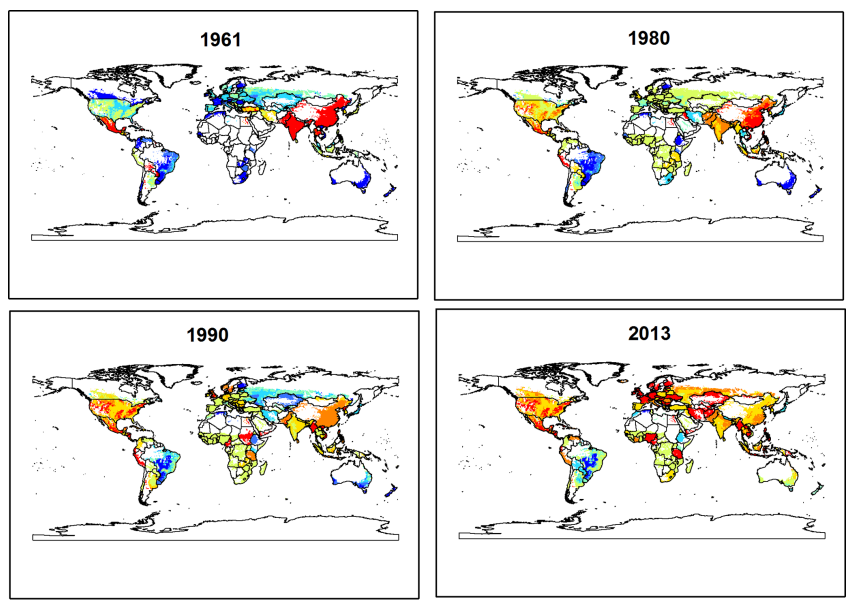

N/P ratio in Fertilizer

(g N/g P)

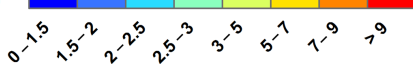

Figure 7. Spatial distribution and changes in $\mathrm{N} / \mathrm{P}$ ratio of synthetic fertilizer application across the world in the years of 1961, 1980, 1990, and 2013.

from Fertilizer Use by Crop 2002 in the development of the other two data products, which led to different spatial details; and (3) the IFA crop-specific fertilizer use data in our study include 13 crop groups (i.e., major crops and groups of others) in each country (Fig. 2), while crop types range from 2 to over 50 per country. This was reported in the IFA crop fertilizer use data that is used in Potter et al. (2010) and Mueller et al. (2012). Therefore, our data may to some extent diminish the cross-crop variations in fertilizer application by using records of crop groups for these nonmajor crop types.

\subsection{Change in $\mathrm{N}$ and $\mathrm{P}$ fertilizer use}

Global synthetic $\mathrm{N}$ and $\mathrm{P}$ fertilizer use increased by $85 \mathrm{Tg} \mathrm{Nyr}^{-1}$ and $10 \mathrm{Tg} \mathrm{Pyr}^{-1}$, respectively, between the 1960s and the last 5 years (2009-2013). Across the region, southern Asia (this region includes East Asia, South Asia, and Southeast Asia; Fig. 9) accounted for $71 \%$ of the enhanced global $\mathrm{N}$ fertilizer use, followed by North America $(11 \%)$, Europe $(7 \%)$, and South America $(6 \%)$. The other three continents shared the remaining $5 \%$ increase. Southern Asia is also the largest contributor $(91 \%)$ to global $\mathrm{P}$ fertilizer use increase over the past half century, followed by South America (21\%) and North America (4\%), while a decrease in $\mathrm{P}$ fertilizer consumption $(-17 \%)$ is found in Europe and negligible change is found in other continents. Noticeably, southern Asia ranks as a top hot spot of global anthropogenic nutrient input, contributing to a number of ecological and environmental problems, such as increased agricultural $\mathrm{N}_{2} \mathrm{O}$ emission, climate warming, nitrate and phosphate leaching, and coastal eutrophication and hypoxia (Seitzinger et al., 2010; Bouwman et al., 2013b; Tian et al., 2016). 
Table 1. Comparison of synthetic $\mathrm{N}$ and $\mathrm{P}$ fertilizer use amount between this study and other existing data sources.

\begin{tabular}{|c|c|c|c|}
\hline Data source & Other estimates & This study & Year \\
\hline \multicolumn{4}{|c|}{ Synthetic $\mathrm{N}$ fertilizer amount $\left(\mathrm{Tg} \mathrm{N} \mathrm{yr}^{-1}\right)$} \\
\hline Van der Hoek and Bouwman (1999) & 73.6 & 70.4 & 1994 \\
\hline Sheldrick et al. (2002) & 78.2 & 80.3 & 1996 \\
\hline Boyer et al. (2004) & 81.1 & \multirow{4}{*}{76.2} & \multirow{4}{*}{1995} \\
\hline Green et al. (2004) & 78.3 & & \\
\hline Siebert (2005) & 72.3 & & \\
\hline Bouwman et al. (2005) & 82.9 & & \\
\hline Potter et al., 2010 & 70.2 & \multirow{4}{*}{80.1} & \multirow{4}{*}{2000} \\
\hline Mueller et al. (2012) & 77.8 & & \\
\hline IFA & 82.1 & & \\
\hline FAO stat & 80.8 & & \\
\hline IFA & 110.2 & \multirow{2}{*}{107.6} & \multirow{2}{*}{2013} \\
\hline FAO stat & 99.6 & & \\
\hline \multicolumn{4}{|c|}{ Synthetic $\mathrm{P}$ fertilizer amount $\left(\mathrm{Tg} \mathrm{Pyr}^{-1}\right)$} \\
\hline Sheldrick et al. (2002) & 12.7 & 13.2 & 1996 \\
\hline Smil (2000) & 15 & \multirow{6}{*}{13.9} & \multirow{6}{*}{2000} \\
\hline Bouwman et al. (2009) & 13.8 & & \\
\hline Potter et al. (2010) & 14.3 & & \\
\hline Mueller et al. (2012) & 13.7 & & \\
\hline IFA & 14.3 & & \\
\hline FAO stat & 14.2 & & \\
\hline IFA & 18.8 & \multirow{2}{*}{17.5} & \multirow{2}{*}{2013} \\
\hline FAO stat & 16.7 & & \\
\hline
\end{tabular}
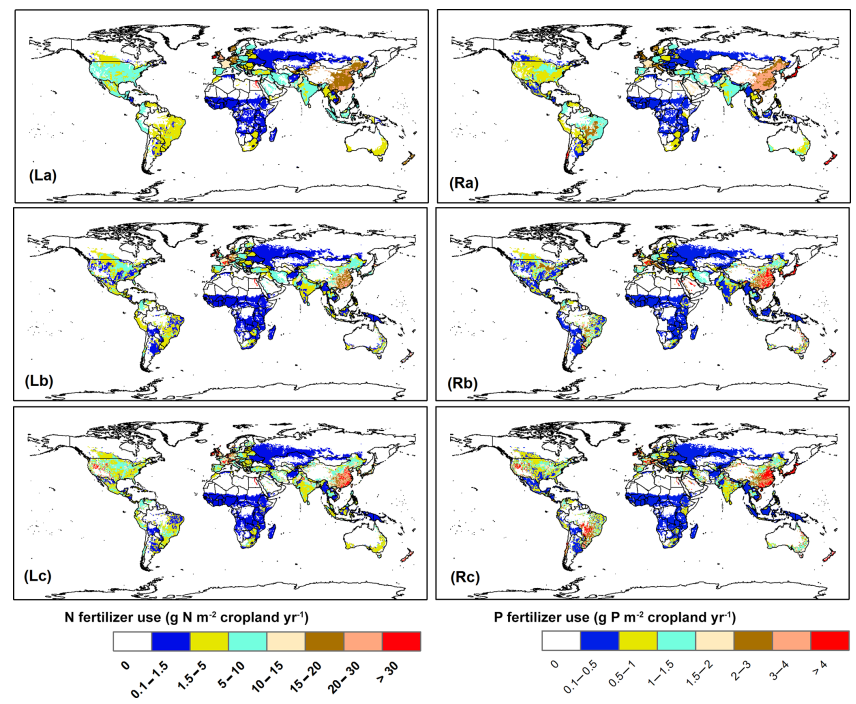

Figure 8. Comparison of global $\mathrm{N}$ and $\mathrm{P}$ fertilizer use maps from this study (a), Potter et al. (2010) (b), and Mueller et al. (2012) (c) in the year 2000. Left panels (La-Lc) indicate $\mathrm{N}$ fertilizer use rate and right panels $(\mathrm{Ra}-\mathrm{Rc})$ indicate $\mathrm{P}$ fertilizer use in units of $\mathrm{g} \mathrm{N}$ or $\mathrm{P} \mathrm{m}^{-2}$ cropland $\mathrm{yr}^{-1}$.

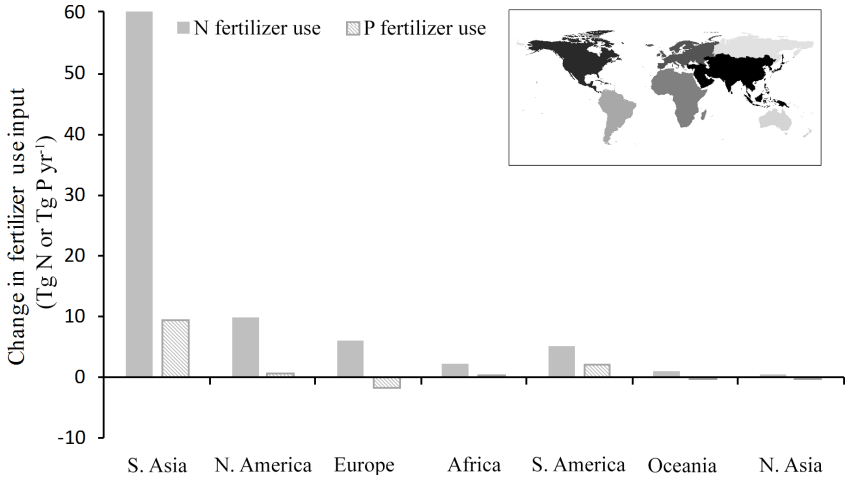

Figure 9. Changes in $\mathrm{N}$ and $\mathrm{P}$ fertilizer use (Tg N or Tg Pyr$\left.{ }^{-1}\right)$ between the 1960s and the last 5 years (2009-2013). Upper right panel shows delineation of seven continents across the globe.

$\mathrm{N} / \mathrm{P}$ ratio in terrestrial plant species is $12-13$ on average, with large cross-species and cross-site variability (Elser et al., 2000; Knecht and Goransson, 2004). Human management, such as fertilizer application, can change $\mathrm{N}$ and $\mathrm{P}$ supply and modify vegetation and soil properties of the $\mathrm{N} / \mathrm{P}$ ratio and their responses to increased $\mathrm{N}$ input (Güsewell, 2004). A higher fertilizer $\mathrm{N} / \mathrm{P}$ ratio in the Northern Hemisphere 

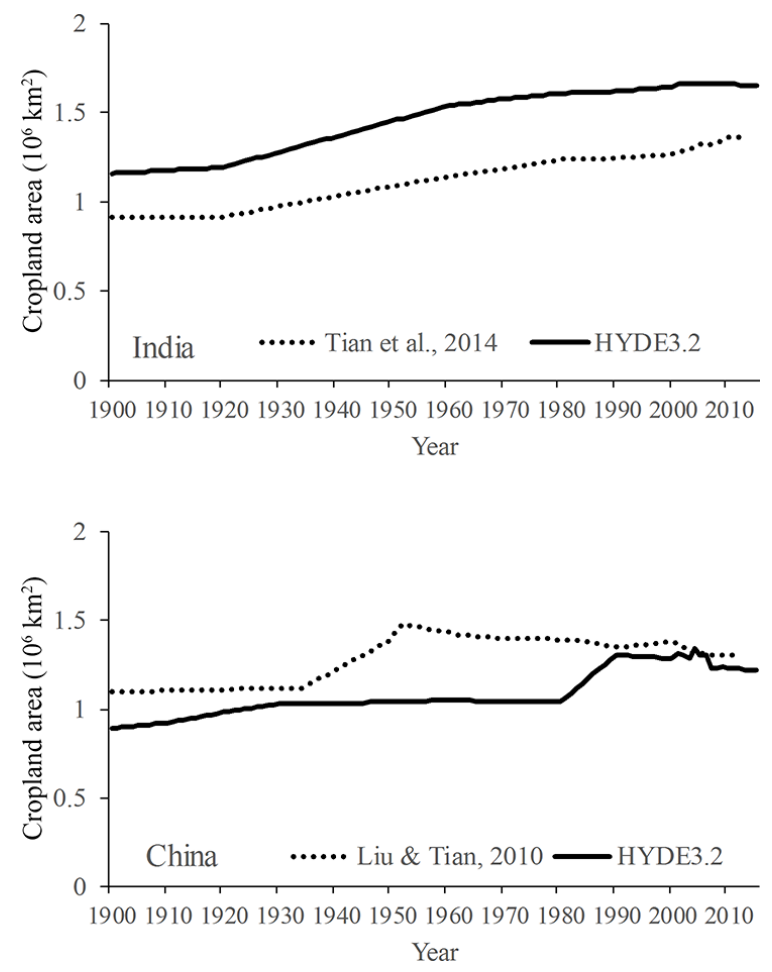

Figure 10. Differences in historical cropland area between highresolution satellite-derived regional LCLUC data (China: Liu and Tian, 2010; India: Tian et al., 2014) and HYDE 3.2 (Klein Goldewijk, 2016) during 1900-2013.

(Fig. 7) could be reasonably explained by $\mathrm{N}$ fertilizer increasing faster than $\mathrm{P}$ fertilizer in historically N-limited and P-rich soil in those areas. Particularly in Europe, $\mathrm{P}$ fertilizer use rate declined, while $\mathrm{N}$ input continued increasing. Fertilizer N / P ratio decline in China and India, however, indicates a shift from nearly zero-synthetic $\mathrm{P}$ fertilizer input to a gradually balanced fertilizer strategy (Zhang et al., 2005). In contrast, South America is characterized by a lower fertilizer N / P ratio because of its large increase in both $\mathrm{N}$ and $\mathrm{P}$ fertilizer use (accounting for 6 vs. $21 \%$ of the global increase since the 1980s; Fig. 9). In the long term, global increase of anthropogenic N / P ratio is expected to reduce species richness (Güsewell et al., 2005), induce the shift from $\mathrm{N}$ limitation to P limitation (Elser et al., 2009; Peñuelas et al., 2012), and increase $\mathrm{N}$ loss (e.g., $\mathrm{N}$ loads to downstream aquatic ecosystems, $\mathrm{NH}_{3}$ volatilization and redeposition elsewhere) due to the limitation of low soil $\mathrm{P}$ availability to $\mathrm{N}$ fertilization effect (Carpenter et al., 1998). To better manage agroecosystem productivity and its sustainability, the dynamic pattern of anthropogenic N / P input ought to be related to local soil $\mathrm{N}$ and $\mathrm{P}$ status, growth demand of different crop species, and historical nutrient inputs.

\subsection{Uncertainty and future needs}

The uncertainties of this database are mainly from the following aspects: (1) the data of country-level fertilizer use by crop we used in this study are from the latest estimate (i.e., 2010 2011; Heffer, 2013), which could reflect current patterns of crop-specific fertilizer application rate, but in the meantime may bias the historical allocation of fertilizer use among crop groups. There are no long-term data indicating how variable the relative contribution of crop groups is in consuming fertilizer at country level. Here, we assume that the evolution of global crop production and crop area, rather than cropspecific fertilizer application rate, is the major reason responsible for the sharing of fertilizer use amongst crops. (2) The spatial pattern of various crop types is derived from M3-crop (Monfreda et al., 2008), which is the most complete and detailed distribution map of 175 crop types so far, though it represents an average status for 1997-2003. By using the information of distribution and harvested area for $13 \mathrm{crop}$ groups from M3-crop, we convert crop-specific fertilizer use amount in each country to gridded agricultural fertilizer use rate in per unit cropland area. The temporal mismatch between fertilizer and crop distribution data may cause underor overestimation of grid-level fertilizer use rate. (3) We assume that the data of M3-crop can capture the contemporary area proportion of crop groups well globally and this proportion is unchanged over time, due to the lack of long-term data sources. Detailed time series information of grid-level crops and the area ratio amongst them could help us to generate more accurate spatial maps of fertilizer use and assess yearly changes due to the changing cropping system. (4) We use HYDE 3.2 historical cropland percentage to spatialize country-level fertilizer use amount from the IFA, but HYDE data are proven to show inconsistent spatial and temporal patterns of cropland area change compared to satellite-derived land use databases on a regional scale (e.g., China (Liu and Tian, 2010) and India (Tian et al., 2014); Fig. 10). Based on high-resolution satellite images and historical archives, the land use data from Liu and Tian (2010) show more concentrated cropland distribution with higher within-grid crop percentage on the North China Plain compared to HYDE 3.2 , although national total cropland area is quite similar between these two data sets in the recent decade. This might be the reason that our data fail to capture the extremely high fertilizer use rate on the North China Plain (more than $40 \mathrm{~g} \mathrm{~N} \mathrm{~m}^{-2}$ cropland $\mathrm{yr}^{-1}$ as indicated in Lu and Tian, 2013, who used land use data from Liu and Tian, 2010). In addition, the difference in national cropland area between HYDE3.2 and the regional LCLUC database (Fig. 10) could make our fertilizer data underestimate average fertilizer use rate per square meter of cropland in India and overestimate fertilizer use rate before 1990 in China. As a result, the extensive distribution of cropland and fertilizer use data in China derived from HYDE 3.2 may lead to uncertain estimates in Earth system modeling. (5) We assume that agricultural fertilizer is all 
consumed in croplands, with no application in grassland or permanent pasture. This assumption overestimates fertilizer use rate in croplands, particularly for those countries with a large proportion of grassland fertilization (e.g., Ireland; Lassaletta et al., 2014). Therefore, we call for a continuous survey of crop-specific fertilizer use, development of dynamic crop-type maps, and updated global land use data with more precise regional patterns for further improving characterization of geospatial and temporal patterns of agricultural fertilizer use.

\section{Data availability}

Agricultural nitrogen and phosphorous fertilizer use data are available at doi:10.1594/PANGAEA.863323 (Lu and Tian, 2016).

\section{Conclusions}

Synthetic $\mathrm{N}$ and $\mathrm{P}$ fertilizer application during agricultural production is a critical component of anthropogenic nutrient input in the Earth system. Development of spatially explicit time series $\mathrm{N}$ and $\mathrm{P}$ fertilizer uses across global cropland reveals a significant and imbalanced increase in $\mathrm{N}$ and $\mathrm{P}$ during the past half century (1961-2013). The hot spots of agricultural nutrient input shifted from North American and European countries to eastern Asia, which implies corresponding changes in the spatial pattern of global nutrient budget, carbon sequestration and storage, greenhouse gas emissions, and riverine nutrient export to downstream aquatic systems. Meanwhile, Africa is still characterized by low nutrient input along with expanding cropland areas. The increased fertilizer $\mathrm{N} / \mathrm{P}$ ratio is likely to alter the nutrient limitation status in agricultural land and affect ecosystem responses to future $\mathrm{N}$ enrichment long term. Agricultural management practices should put emphasis on increasing nutrient use efficiency in those high-input regions, while reducing environmental and ecological consequences of excessive nutrient loads and enhancing agricultural fertilizer application to relieve nutrient limitation in low-input regions. In addition to meeting different fertilizer demands spatially, balanced $\mathrm{N}: \mathrm{P}: \mathrm{K}$ fertilizer application ought to be promoted depending on local nutrient availability and crop growth demands.

Competing interests. The authors declare that they have no conflict of interest.

Acknowledgements. This work has been supported by Iowa State University new faculty start-up funds, NSF Grants (AGS1243232, CNH1210360), and the State Key Laboratory of Urban and Regional Ecology, RCEES, Chinese Academy of Sciences. We thank the anonymous reviewers for their precious comments and constructive suggestions for improving this paper.
Edited by: D. Carlson

Reviewed by: two anonymous referees

\section{References}

Banger, K., Tian, H., Tao, B., Ren, W., Pan, S., Dangal, S., and Yang, J.: Terrestrial net primary productivity in India during 1901-2010: contributions from multiple environmental changes, Climatic Change, 132, 575-588, 2015.

Bouwman, A. F., Van Drecht, G., Knoop, J. M., Beusen, A. H. W., and Meinardi, C. R.: Exploring changes in river nitrogen export to the world's oceans, Global Biogeochem. Cy., 19, GB1002, doi:10.1029/2004GB002314, 2005.

Bouwman, A. F., Beusen, A. H. W., and Billen, G.: Human alteration of the global nitrogen and phosphorus soil balances for the period 1970-2050, Global Biogeochem. Cy., 23, GB0A04, doi:10.1029/2009GB003576, 2009.

Bouwman, A. F., Beusen, A. H. W., Griffioen, J., Van Groenigen, J. W., Hefting, M. M., Oenema, O., Van Puijenbroek, P. J. T. M., Seitzinger, S., Slomp, C. P., and Stehfest, E.: Global trends and uncertainties in terrestrial denitrification and $\mathrm{N}_{2} \mathrm{O}$ emissions, Philos. T. R. Soc. B, 368, 20130112, doi:10.1098/rstb.2013.0112, 2013b.

Bouwman, L., Goldewijk, K. K., Van Der Hoek, K. W., Beusen, A. H., Van Vuuren, D. P., Willems, J., Rufino, M. C., and Stehfest, E.: Exploring global changes in nitrogen and phosphorus cycles in agriculture induced by livestock production over the 19002050 period, P. Natl. Acad. Sci., 110, 20882-20887, 2013a.

Carpenter, S. R., Caraco, N. F., Correll, D. L., Howarth, R. W., Sharpley, A. N., and Smith, V. H.: Nonpoint pollution of surface waters with phosphorus and nitrogen, Ecol. Appl., 8, 559-568, 1998.

Elser, J. J., Sterner, R. W., Gorokhova, E., Fagan, W. F., Markow, T. A., Cotner, J. B., Harrison, J. F., Hobbie, S. E., Odell, G. M., and Weider, L. W.: Biological stoichiometry from genes to ecosystems, Ecol. Lett., 3, 540-550, 2000.

Elser, J. J., Andersen, T., Baron, J. S., Bergström, A. K., Jansson, M., Kyle, M., Nydick, K. R., Steger, L., and Hessen, D. O.: Shifts in lake N: P stoichiometry and nutrient limitation driven by atmospheric nitrogen deposition, Science, 326, 835-837, 2009.

Erisman, J. W. and Sutton, M. A., Galloway, J., Klimont, Z., and Winiwarter, W.: How a century of ammonia synthesis changed the world, Nat. Geosci., 1, 636-639, 2008.

FAOSTAT (Food and Agriculture Organization Corporate Statistical Database): FAO online database, available at: http://faostat3. fao.org/browse/G1/*/E (last access: 5 January 2017), 2015.

Galloway, J. N., Dentener, F. J., Capone, D. G., Boyer, E. W., Howarth, R. W., Seitzinger, S. P., Asner, G. P., Cleveland, C. C., Green, P. A., Holland, E. A., and Karl, D. M.: Nitrogen cycles: past, present, and future, Biogeochem., 70, 153-226, 2004.

Global Administrative Areas: GADM database of Global Administrative Areas, version 2.0, availanle at: http://www.gadm.org (last access: 5 January 2017), 2012.

Green, P. A., Vörösmarty, C. J., Meybeck, M., Galloway, J. N., Peterson, B. J., and Boyer, E. W.: Pre-industrial and contemporary fluxes of nitrogen through rivers: a global assessment based on typology, Biogeochemistry, 68, 71-105, 2004. 
Guo, J. H., Liu, X. J., Zhang, Y., Shen, J. L., Han, W. X., Zhang, W. F., Christie, P., Goulding, K. W. T., Vitousek, P. M., and Zhang, F. S.: Significant acidification in major Chinese croplands, Science, 327, 1008-1010, 2010.

Güsewell, S.: N:P ratios in terrestrial plants: variation and functional significance, New Phytol., 164, 243-266, 2004.

Güsewell, S., Bailey, K. M., Roem, W. J., and Bedford, B. L.: Nutrient limitation and botanical diversity in wetlands: can fertilisation raise species richness?, Oikos, 109, 71-80, 2005.

Heffer, P.: Assessment of fertilizer use by crop at the global level 2010-2010/11, International Fertilizer Industry Association, Paris, available at: http://www.fertilizer.org/ItemDetail? iProductCode $=9592$ Pdf $\&$ Category $=$ STAT $\&$ WebsiteKey (last access: 15 December 2017) 2013.

Ivanova, S. and Nosov, V.: Development of agriculture in Russia and its impact on fertilizer use, International Plant Nutrition Institute, available at: http://eeca-en.ipni.net/article/EECAEN-2025, 2011.

Ju, X. T., Xing, G. X., Chen, X. P., Zhang, S. L., Zhang, L. J., Liu, X. J., Cui, Z. L., Yin, B., Christie, P., Zhu, Z. L., and Zhang, F. $\mathrm{S}$.: Reducing environmental risk by improving $\mathrm{N}$ management in intensive Chinese agricultural systems, P. Natl. Acad. Sci. USA, 106, 3041-3046, 2009.

Klein Goldewijk, K.: A historical land use data set for the Holocene; HYDE 3.2, DANS, doi:10.17026/dans-znk-cfy3, 2016.

Knecht, M. F. and Göransson, A.: Terrestrial plants require nutrients in similar proportions, Tree Physiol., 24, 447-460, 2004.

Lassaletta, L., Billen, G., Grizzetti, B., Anglade, J., and Garnier, J.: 50 year trends in nitrogen use efficiency of world cropping systems: the relationship between yield and nitrogen input to cropland, Environ. Res. Lett., 9, p. 105011, 2014.

Liu, M. and Tian, H.: China's land cover and land use change from 1700 to 2005: Estimations from high-resolution satellite data and historical archives, Global Biogeochem. Cy., 24, GB3003, doi:10.1029/2009GB003687, 2010.

Lu, C. and Tian, H.: Net greenhouse gas balance in response to nitrogen enrichment: perspectives from a coupled biogeochemical model, Glob. Change Biol., 19, 571-588, 2013.

Lu, C. and Tian, H.: Half-degree gridded nitrogen and phosphorus fertilizer use for global agriculture production during 19002013, doi:10.1594/PANGAEA.863323, 2016.

Monfreda, C., Ramankutty, N., and Foley, J. A.: Farming the planet: 2. Geographic distribution of crop areas, yields, physiological types, and net primary production in the year 2000, Global Biogeochem. Сy., 22, GB1022, doi:10.1029/2007GB002947, 2008.

Mosier, A., Kroeze, C., Nevison, C., Oenema, O., Seitzinger, S., and Van Cleemput, O.: Closing the global $\mathrm{N}_{2} \mathrm{O}$ budget: nitrous oxide emissions through the agricultural nitrogen cycle, Nutr. Cycl. Agroecosys., 52, 225-248, 1998.

Mueller, N. D., Gerber, J. S., Johnston, M., Ray, D. K., Ramankutty, N., and Foley, J. A.: Closing yield gaps through nutrient and water management, Nature, 490, 254-257, 2012.

Peñuelas, J., Sardans, J., Rivas-ubach, A., and Janssens, I. A.: The human-induced imbalance between $\mathrm{C}, \mathrm{N}$ and $\mathrm{P}$ in Earth's life system, Glob. Change Biol., 18, 3-6, 2012.

Potter, P., Ramankutty, N., Bennett, E. M., and Donner, S. D.: Characterizing the spatial patterns of global fertilizer application and manure production, Earth Interact., 14, 1-22, 2010.
Seitzinger, S. P., Mayorga, E., Bouwman, A. F., Kroeze, C., Beusen, A. H. W., Billen, G., Van Drecht, G., Dumont, E., Fekete, B. M., Garnier, J., and Harrison, J. A.: Global river nutrient export: A scenario analysis of past and future trends, Global Biogeochem. Cy., 24, GB0A08, doi:10.1029/2009GB003587, 2010.

Sheldrick, W. F., Syers, J. K., and Lingard, J.: A conceptual model for conducting nutrient audits at national, regional, and global scales, Nutr. Cycl. Agroecosys., 62, 61-72, 2002.

Siebert, S.: Global-scale modeling of nitrogen balances at the soil surface. Frankfurt Hydrol. Pap., 2, 35 pp., Inst. of Phys. Geogr., Frankfurt Univ., Frankfurt am Main, Germany, 2005.

Smil, V.: Nitrogen and food production: proteins for human diets, AMBIO, 31, 126-131, 2002.

Stocker, B. D., Roth, R., Joos, F., Spahni, R., Steinacher, M., Zaehle, S., Bouwman, L., and Prentice, I. C.: Multiple greenhouse-gas feedbacks from the land biosphere under future climate change scenarios, Nature Climate Change, 3, 666-672, 2013.

Sutton, M. A., Oenema, O., Erisman, J. W., Leip, A., van Grinsven, H., and Winiwarter, W.: Too much of a good thing, Nature, 472, 159-161, 2011.

Tian, H., Xu, X., Liu, M., Ren, W., Zhang, C., Chen, G., and Lu, C.: Spatial and temporal patterns of $\mathrm{CH}_{4}$ and $\mathrm{N}_{2} \mathrm{O}$ fluxes in terrestrial ecosystems of North America during 1979-2008: application of a global biogeochemistry model, Biogeosciences, 7, 2673-2694, doi:10.5194/bg-7-2673-2010, 2010.

Tian, H., Lu, C., Melillo, J., Ren, W., Huang, Y., Xu, X., Liu, M., Zhang, C., Chen, G., Pan, S., and Liu, J.: Food benefit and climate warming potential of nitrogen fertilizer uses in China, Environ. Res. Lett.,7, 044020, doi:10.1088/1748-9326/7/4/044020, 2012.

Tian, H., Banger, K., Bo, T., and Dadhwal, V. K.: History of land use in India during 1880-2010: Large-scale land transformations reconstructed from satellite data and historical archives, Global Planet. Change, 121, 78-88, 2014.

Tian, H., Chen, G., Lu, C., Xu, X., Ren, W., Zhang, B., Banger, K., Tao, B., Pan, S., Liu, M., and Zhang, C.: Global methane and nitrous oxide emissions from terrestrial ecosystems due to multiple environmental changes, Ecosystem Health and Sustainability, 1, 1-20, 2015.

Tian, H., Lu, C., Ciais, P., Michalak, A. M., Canadell, J. G., Saikawa, E., Huntzinger, D. N., Gurney, K. R., Sitch, S., Zhang, B., Yang, J., Bousquet, P., Bruhwiler, L., Chen, G., Dlugokencky, E., Friedlingstein, P., Melillo, J., Pan, S., Poulter, B., Prinn, R., Saunois, M., Schwalm, C. R., and Wofsy, S. C.: The terrestrial biosphere as a net source of greenhouse gases to the atmosphere, Nature, 531, 225-228, 2016.

Tilman, D., Cassman, K. G., Matson, P. A., Naylor, R., and Polasky, S.: Agricultural sustainability and intensive production practices, Nature, 418, 671-677, 2002.

Van der Hoek, K. W. and Bouwman, A. F.: Upscaling of nutrient budgets from agroecological niche to global scale, in: Nutrient disequilibria in agroecosystems, edited by: Smaling, E. M. A., Oenema, O., and Fresco, L. O., Wallingford, CABI Publishing, 57-73, 1999.

Vitousek, P. M., Mooney, H. A., Lubchenco, J., and Melillo, J. M.: Human domination of Earth's ecosystems, Science, 277, 494499, 1997.

Vitousek, P. M., Naylor, R., Crews, T., David, M. B., Drinkwater, L. E., Holland, E., Johnes, P. J., Katzenberger, J., Martinelli, L. 
A., Matson, P. A., and Nziguheba, G.: Nutrient imbalances in agricultural development, Science, 324, 1519-1520, 2009.

Zaehle, S., Ciais, P., Friend, A. D., and Prieur, V.: Carbon benefits of anthropogenic reactive nitrogen offset by nitrous oxide emissions, Nat. Geosci., 4, 601-605, 2011.
Zhang, C., Tian, H., Liu, J., Wang, S., Liu, M., Pan, S., and Shi, $\mathrm{X}$.: Pools and distributions of soil phosphorus in China, Global Biogeochem. Cy., 19, GB1020, doi:10.1029/2004GB002296, 2005. 